Elsevier Editorial System(tm) for Ecological
Engineering or its open access mirror
Manuscript Draft

Manuscript Number:

Title: EARLY COLONIZATION OF CONSTRUCTED TECHNOSOL BY MICROARTHROPODS

Article Type: Research Paper

Keywords: Constructed Technosols; Colonization; Microarthropods; Collembolans

Corresponding Author: Dr. Lucia Santorufo,

Corresponding Author's Institution: University of Naples Federico II

First Author: Lucia Santorufo

Order of Authors: Lucia Santorufo; Sophie Joimel; Apolline Auclerc; Jules Deremiens; Gilles Grisard; Mickael Hedde; Johanne Nahmani; Celine Pernin; Jerome Cortet

Abstract: The construction of Technosol using recycled waste material is considered an appealing sustainable use of both natural and anthropic resources. Constructed Technosol can attract and host a multitude of soil organisms, forming a reserve of biodiversity. In this study, we assessed the early colonization - in successional stages - of a constructed Technosol supporting grassland vegetation by the microarthropod community, in particular collembola. To do this, the taxonomic and functional characteristics of microarthropod communities in a newly constructed Technosol in northeast France were studied for a period of four years. The results found that colonization by microarthropods was characterized by an increasing number of individuals over time. Collembola communities also increased in density and taxonomic richness, as well as in functional richness and dispersion. However, hemiedaphic Collembola dominated the community, particularly in the fourth year. Findings at the end of the survey indicated that the Collembola community in the studied Technosol remained very different to that of natural grassland, while it shared some characteristics with arable land. 


\section{EARLY COLONIZATION OF CONSTRUCTED TECHNOSOL BY MICROARTHROPODS}

Lucia Santorufo $^{1^{*}}$, Sophie Joimel ${ }^{2}$, Apolline Auclerc ${ }^{3}$, Jules Deremiens ${ }^{4}$, Gilles Grisard ${ }^{3}$, Mickaël Hedde $^{5}$, Johanne Nahmani ${ }^{4}$, Céline Pernin ${ }^{6}$, Jerome Cortet ${ }^{4}$

${ }^{1}$ Department of Biology, University of Naples “Federico II”, via Cinthia, 80126 Naples, Italy

2 ECOSYS (Functional Ecology and Ecotoxicology of Agrosystems, UMR 1402), INRAE, AgroParisTech, Université Paris-Saclay, 78850, Thiverval-Grignon, France

3 INRAE, Université de Lorraine, ENSAIA, LSE (Soil and Environment Laboratory), F-54500 Vandoeuvre-les-Nancy, France

${ }^{4}$ CEFE (Centre of Functional and Evolutionary Ecology, UMR 5175), Université Paul Valéry Montpellier 3, CNRS, Université de Montpellier, EPHE, IRD, F-34000 Montpellier, France

${ }^{5}$ Eco\&Sols (Functional Ecology and Biochemistry of Soils and Agro-ecosystems, UMR 1222), INRAE, Montpellier SupAgro, Cirad, F-34000 Montpellier, France

${ }^{6}$ Université de Lille, LGCgE (Laboratory of Civil and Geo-environmental Engineering, EA 4515), F-59655 Villeneuve d'Asq cedex, France

*Corresponding author: Dr. Lucia Santorufo; tel.: + 39081 679111; fax: +39 081 679223;

e-mail: lucia.santorufo@unina.it 


\begin{abstract}
The construction of Technosol using recycled waste material is considered an appealing sustainable use of both natural and anthropic resources. Constructed Technosol can attract and host a multitude of soil organisms, forming a reserve of biodiversity. In this study, we assessed the early colonization - in successional stages - of a constructed Technosol supporting grassland vegetation by the microarthropod community, in particular Collembola. To do this, the taxonomic and functional characteristics of microarthropod communities in a newly constructed Technosol in northeast France were studied for a period of four years. The results found that colonization by microarthropods was characterized by an increasing number of individuals over time. Collembola communities also increased in density and taxonomic richness, as well as in functional richness and dispersion. However, hemiedaphic Collembola dominated the community, particularly in the fourth year. Findings at the end of the survey indicated that the Collembola community in the studied Technosol remained very different to that of natural grassland, while it shared some characteristics with arable land.
\end{abstract}

Keywords: Constructed Technosols; Colonization; Microarthropods; Collembolans 


\section{Introduction}

On the Earth today, humans have manipulated every type of ecosystem, treating natural resources as if they were infinite. According to the UN Food and Agriculture Organization (FAO, 2015), one-third of the world's soils are moderately or severely degraded, and in Europe $16 \%$ of the total land area is affected by several kinds of degradation processes (Soil Atlas Europe, 2005). Moreover, the continual use of natural resources for human development produces a large amount of waste, including green waste, rubble, household refuse, industrial waste and by-products (Rokia et al., 2014). These materials are often not valorized: while some are recycled for industrial processes (ADEME, 2015; VidalBeaudet, 2018), most end up in waste storage facilities (Marshall and Farahbakhsh, 2013). To manage ecosystems more sustainably, it is critical to optimize the use of local resources by systematically recovering and valorizing energy, water, building materials and waste. Reclaiming waste material instead of using natural resources is an environmental priority.

Recycling waste in order to construct Technosols is now considered a potential economic opportunity as it can reduce the costs associated with civil engineering. Constructed Technosols are soils engineered by combining organic and mineral anthropogenic materials derived from human activities (Lehmann, 2006). The properties and pedogenesis of these soils are dominated by their technical origin (Yilmaz et al., 2019).

Several studies have shown that constructed Technosols are able to support important soil functions, such as the production of biomass and the filtration of water (Séré et al., 2008), the storage of available water for plants (Yilmaz et al., 2018), the creation of porosity and aggregates (Jangorzo et al., 2013; Deeb et al., 2016, 2017), and the transformation of organic matter (Grosbellet et al., 2011). This research suggests that these artificial soils can help to reclaim derelict lands and provide suitable conditions for soil organisms. The studies conducted on Technosols have highlighted that they can attract and host a multitude of soil organisms, forming an important reserve of biodiversity. Hafeez et 
al. (2012) found a high diversity of microorganisms in Technosols; however, succession processes in constructed Technosols led to the homogenization of the microbial community. Studies conducted on the nematode community (Villenave et al., 2018) have shown the rapid colonization of Technosols, with a succession of nematode communities established during the study. In other studies, macroinvertebrates, which were absent at the beginning of monitoring, rapidly colonized the Technosols after construction (Hedde et al., 2018).

These promising results encourage investigation into the colonization dynamics of other invertebrates to better understand the potential of Technosols in hosting soil organisms. Of these, Collembola are small arthropods that play an essential role in soil functioning (e.g. in the decomposition of organic matter, humus formation, nutrient cycling, etc.). In addition, through their movement they disperse microorganisms and are food sources for many predators (Vanhee and Devigne, 2018). Collembola are considered useful biological indicators, as they respond to environmental changes with taxonomic and functional alterations in community structure (Salmon and Ponge, 2012; Ponge et al., 2013; Martins da Silva et al., 2015). Despite the tendency to regard Collembola as rather sedentary creatures, they have an astonishing ability to disperse, especially by air (Dunger, 1989; Hopkin, 1997; Joimel et al., 2018). Due to their dispersive powers (Hopkin, 1997), collembolans are among the first to arrive in soil (Dunger and Wanner, 1999), which makes them successful early colonizers of reclaimed lands. While the colonization of degraded or disturbed soils by Collembola has been reported (Chauvat and Ponge, 2002; Dunger et al., 2002; Hågvar, 2010), the colonization of artificial soils and the early stages of community succession by these arthropods has been less studied.

To address this, this study aimed to investigate the early colonization (the first four years) by Collembola of a constructed Technosol supporting grassland vegetation in order to shed light on the successional stages of the community in this environment. The development of vegetation on 
Technosol should create a mosaic of microenvironments (Winter et al., 2019). In turn, the increasing heterogeneity of the environments and niches should facilitate colonization by organisms from surrounding environments, resulting in increased Collembola diversity. We also expected Collembola community composition to change over time, with hemiedaphic organisms dominant at the beginning of the Technosol construction, due to the introduction of compost, and an increase of epedaphic organisms over time with the development of vegetation. Specifically, our hypotheses were that: a) Collembola taxonomic composition would change over the study period, becoming increasingly rich in species, b) functional diversity would increase over time, and c) after four years, the Collembola community structure would tend to be similar to a typical grassland community in the geographical area.

\section{Material and methods}

\subsection{Study area}

The study was carried out at an industrial wasteland site in France (in Homécourt, in the region of Lorraine, northeast France). The area has a continental climate, with a mean rainfall of $760 \mathrm{~mm}^{-1}$ and a mean temperature of $10^{\circ} \mathrm{C}$. For the experiment, a 1-hectare plot was created in the autumn of 2007. This field was divided into 24 numbered $20 \mathrm{~m} \times 20 \mathrm{~m}$ subplots.

\subsection{Experimental design of the Technosol}

The experimental design we implemented and the soil properties are described in detail in several publications (Hafeez et al., 2012; Hedde et al., 2018; Villenave et al., 2018). In summary, the Technosol was constructed using three distinct technogenic parent materials: paper-mill sludge (PS), thermally treated industrial soil (TIS), and green-waste compost (GWC). These parent materials had been previously decontaminated, showing trace elements of metals and polycyclic aromatic hydrocarbons (PAH) at levels close to natural soils. Our experimental soil was classified as a Spolic 
Garbic Hydric Technosol (Calcaric) (IUSS Working Group WRB 2014).

In order to establish grassland, a mixture of grass plants was seeded in November 2007 (30\% Lolium perenne, var. Tove; 40\% Festuca arundinacea, var. Fuego; 30\% Dactylis glomerata, var. $A m b a)$. The vegetation was mown and mulched twice a year without any biomass exportation. The average dry biomass production over the four-year study period (2008 to 2011) was $3 \mathrm{t} \mathrm{ha}^{-1}$, which is comparable to neighbouring natural extensive grasslands.

\subsection{Microarthropod sampling and collembolan analysis}

Core samples were taken from the surface soil ( 0 to $5 \mathrm{~cm}$ deep, $5 \mathrm{~cm}$ diameter) within each of the 24 subplots in the first half of April of each year (2008 to 2011). Four cores were collected in each subplot at each date. The microarthropods were then extracted using the MacFadyen method over a one-week period (Cortet et al., 2007) and sorted using a dissecting stereomicroscope. The microarthropods were categorized into three groups: Acari, Collembola and other microarthropods (e.g. pseudoscorpions, small millipedes). When possible, collembolans were identified to species level using relevant identification keys (Gisin, 1960; Bretfeld, 1999; Potapov, 2001).

To study the colonization process, we used a functional trait-based approach based on eight functional traits related to Collembola fitness in terms of growth, reproduction and dispersion (Pey et al., 2014b). These eight traits (Table 1) have been demonstrated to be linked to collembolan dispersal capability and habitat and food source requirements (Makkonen et al., 2011), as well as their response to disturbance or stress (Salmon et al., 2014; Santorufo et al., 2015; Joimel et al., 2018). They relate to body shape, body size, presence of visual organs (ocelli and post-antennal organ), presence of furcula or scales, pigmentation, and reproduction type.

Trait values were extracted from the BETSI database (Biological and Ecological Functional Traits of Soil Invertebrates: https://portail.betsi.cnrs.fr/). The traits were split into attributes by a fuzzy coding approach (Pey et al., 2014a). This type of data transformation allows values to be calculated for 
functional traits derived from a variety of sources - mainly from identification keys (Gisin, 1960; Zimdars and Dunger, 1995; Dunger, 1999; Potapow, 2001; Thibaud et al., 2004; Hopkin, 2007; Dunger and Schlitt, 2011; Jordana, 2012). Body shape, post-antennal organ, furcula development, pigmentation, scales and reproduction type were split into two attributes, visual organs (ocelli) into three, and body length into ten (Table 1).

\subsection{Community indices}

To describe the communities, the density (number of individuals per $\mathrm{m}^{2}$ ) of Acari and 'other arthropods' was quantified year by year, while Collembola communities were described by density (number of individuals per $\mathrm{m}^{2}$ ), taxonomic richness (total number of species), Shannon index, and Pielou evenness index. The values were compared to those provided by Joimel et al. (2017) for various land types (forest, grassland and arable land) to assess rehabilitation success.

We also investigated the response of life-form strategies to Technosol pedogenesis. Species were assigned to the three ecomorphological groups defined by Gisin (1943), which describe their habitat preferences combined with morphological properties: epedaphic species are very mobile organisms that mainly live in litter and topsoil, euedaphic species are not very mobile and live in soil macropores, and hemiedaphic species are intermediate.

In addition, we calculated two distance-based functional diversity indices, which provide information about functional structure. Functional richness represents the volume of the functional space occupied by the community and functional dispersion is the mean distance of all species to the barycentre of the trait space (Laliberte and Legendre, 2010). Functional composition was measured by the community weighted mean (CWM) of each trait, which is the trait's value weighted by species abundance (Lavorel et al., 2008).

\subsection{Statistical analysis}

As the taxonomic and functional indices did not match the basic assumptions of normality and 
homoscedasticity required for parametric statistics (the Wilk-Shapiro test resulted in a rejection level of $\alpha=0.05$ ), we used the Wilcoxon Rank-Sum test with the Bonferroni adjustment to assess differences in abundance and composition and the indices of taxonomic and functional diversity between the four years.

To analyse the dynamics of the composition of collembolan species (presence-absence) over the years, we performed non-metric multidimensional scaling (NMDS) using the Bray-Curtis index, which allowed us to explore dissimilarities between communities. Additionally, we used species' presenceabsence data in other land types (forest, grassland and arable land in France) (Joimel et al., 2017) to compare collembolan community composition in the rehabilitated site with these land types.

A principal component analysis (PCA) was performed on the CWM values assembled in a single matrix (29 taxa x 17 trait CWMs). For binary attributes, only one attribute per taxa was used in the PCA in order to avoid correlation. The PCA column was weighted by the number of trait attributes to maintain the trait's relative weight. Differences in the composition of species and traits over the years were tested by permutational multivariate analysis of variance using distance matrices (ADONIS).

All statistical analyses were performed using R software version 3.5.0 (R Development Core Team, 2015) with packages 'FD' (Laliberté and Shipley, 2011), 'vegan' (Oksanen et al., 2014) and 'ade4' (Dray and Dufour, 2007).

\section{Results}

\subsection{Taxonomic composition and structure of Technosol microarthropod communities}

The findings showed that total microarthropod density increased significantly between the first year and the fourth year (from year 1 to 4 respectively: $11,36,44$ to $5610^{3}$ individuals by $\mathrm{m}^{2}$ ). Of these microarthropods, the proportion of Collembola increased significantly the second year (from $61 \%$ to 79\%) and stayed consistently high thereafter (around 86\%), whereas the proportion of Acari decreased 
(from $30 \%$ the first year to $11 \%$ the fourth year) (Table 2). This composition differed significantly from the composition reported in other land types (forest, arable land and grassland) in France whatever the year, due to the strong dominance of collembolans.

Collembola density increased significantly over the study period, especially between the first and second year (3.6 times higher) (Table 3) and was higher compared to other land types (forest, grassland and arable land) (Fig. 1). A total of 29 Collembola taxa (24 at the species level and 5 at the genus level) were identified; the mean number of taxa varied significantly from 2.9 (the third year) to 4.9 (the fourth year), but was always lower compared to the mean values for French forests and grassland. However, the mean number of taxa in the fourth year was similar to that in arable land.

The Shannon index followed the same gradient as the mean species' value, whereas evenness significantly decreased from the first to the second year ( 0.7 and 0.5 , respectively) and stayed stable thereafter (Table 3).

The representation of the NMDS (Fig. 2) revealed significant differences (ADONIS, p <0.01) between all years. Heterogeneity in species composition tended to decrease over the four years and became closer to other land types, especially arable land. However, the species composition in the constructed Technosol was still different compared to that of grassland after four years.

\subsection{Functional composition and structure of collembolan communities}

The functional structure and composition of Collembola communities changed during the Technosol colonization process. Functional richness was significantly higher the fourth year compared to the first year, although values slightly decreased the second and third year. Functional dispersion (Fdis) did not vary from the first to the third year, whereas it significantly increased in the fourth year. The first two PCA axes of the CWM accounted for $43 \%$ and $21 \%$ of the total inertia (Fig. 3). Axis 1 was negatively correlated with the absence of ocelli, small body size and parthenogenetic reproduction, while it was positively correlated with the presence of pigmentation, furcula, $8+8$ ocelli and spherical body shape. 
Axis 2 was positively correlated with $1+1$ to $7+7$ ocelli, parthenogenetic reproduction and the presence of a post-antennal organ, and negatively with the presence of scales. The first year showed higher variability in CWM composition than other years. Functional traits were significantly differentiated over the four years along axis 1 (ADONIS, $\mathrm{p}<0.01$ ).

Overall, communities were strongly dominated by organisms with sexual reproduction, presence of furcula, pigmentation, ocelli and a post-antennal organ, absence of scales and a cylindrical body shape (Table 4). However, we also noticed significant differences in CWM between years. Two patterns were present: (i) a modification between the first and second year (which remained for the following years) in furcular length ( $87 \%$ to $99 \%$ ), pigmentation presence ( $83 \%$ to $98 \%$ ) and absence of ocelli (17\% to $1 \%$ ) and (ii) a similar composition in the first and fourth years, but which was significantly different from other years. This latter pattern mainly concerned sexual reproduction, which varied from $77 \%$ and $73 \%$ (in the first and last year) to more than $90 \%$ in the years in between, as well as the number of ocelli, especially $8+8$, which was around $55 \%$ in the first and last year and more than $85 \%$ in the years in between. In contrast, less significant differences were observed for the absence of scales, body length and post-antennal organ presence.

Collembola communities were dominated by hemiedaphic species (between $78 \%$ and $99 \%$ of all species), especially from the second year (when they represented more than 98\%). In contrast, the proportion of epedaphic and euedaphic species decreased significantly between the first and second year and remained low for the following years (from $7 \%$ to $1 \%$ for epedaphic species, and from $15 \%$ to less than $1 \%$ for euedaphic species). Whatever the year, the ecomorphological composition in the constructed Technosol was different from that observed in other land types (forest, arable land and grassland) due to the strong dominance of hemiedaphic species.

\section{Discussion}




\section{Colonization of the Technosol by microarthropods}

In our experiment, the constructed Technosol showed successful colonization by microarthropods. In fact, the soil hosted a high number of microarthropods rapidly after construction, which corroborates results found in previous studies (Dunger et al., 2002; Pey, 2010; Burrow et al., 2018). Nonetheless, after a four-year period, the microarthropod community was not yet comparable to a natural grassland, or even to arable land. There was a disproportionate abundance of Collembola in relation to Acari in the experimental Technosol compared to grassland or forest (Table 2). The strong dominance of Collembola relative to Acari in the Technosol may be due to differences in dispersal capability. The dispersal of Acari, especially Oribatida, by active migration is considered negligible or very slow (Behan-Pelletier and Winchester, 1998; Skubala, 2004), whereas the presence of furcula in Collembola may favour spreading and passive settling by wind (Dunger et al., 2002; Joimel et al., 2018). Yet the presence of furcula is apparently not the only controlling factor in Collembola colonization, as species with reduced furcula (i.e. Mesaphorura sp.) also showed fast colonization (Dunger et al., 2002; Vanhée and Devigne, 2018). Other unknown factors would seem to play a role in Collembola dispersal mechanisms.

\section{Taxonomic composition of the Technosol Collembola community}

Collembola density and species richness increased over the four-year survey, confirming our hypothesis that the community would become more numerous and diversified. However, compared to reference values, density was higher and species richness lower. This gap between the Technosol Collembola community and those of other ecosystems could be due to the different degree of maturity of such communities. The high values for Collembola abundance and the lower values for the number of species (Fig. 1a, b) observed in the Technosol each year are typical of immature communities, which show low levels of competition (Korotkevich et al., 2018; Milano et al., 2018). Moreover, the decrease in Collembola evenness over the years suggests that a few species dominated this soil. 
Colonization of an ecological system is a process influenced by a variety of abiotic and biotic factors, but also depends on interspecific interactions and stochastic effects (Melbourne and Hastings, 2009; Clobert et al., 2012). This results in community assemblage dynamics that shift from random associations to interspecific interactions, ultimately reaching a steady state or a dynamic equilibrium within the community (Hedde et al., 2018). Our analysis of the microarthropod community (Fig. 2; Table 2) in the experimental Technosol confirms these mechanisms. During the first year of colonization, species composition represented quite high variability, due to the random assemblage of species. Over time, the species composition tended to homogenize, probably due to more stable interactions with the abiotic and biotic aspects of the ecosystem; by the end of the study, a few common species dominated the Technosol, such as Paristoma notabilis (Schaffer, 1896), Proisotoma minuta (Tullberg, 1871), Hypogastrura manubrialis (Tullberg, 1869) and Lepidocyrtus cyaneus (Tullberg, 1871). It is interesting to note that, at the end of the survey, Collembola species composition was not similar to that found in natural grasslands (Fig. 2). This contradicts our third hypothesis (that after four years, the Collembola community structure would tend to be similar to a typical grassland community in the geographical area), suggesting that the period of experimentation was too short to detect the settlement of a grassland microarthropod community in the Technosol, as was also found by Hedde et al. (2018) for macroarthropod organisms. The Collembola community observed in the Technosol was more similar to that of arable land, known to be among the most disturbed soil systems in France (Joimel et al., 2017). This may be due both to the surrounding environment and their distance to Technosol, partially influencing organism abundance (Pey, 2010), as well as to the physico-chemical characteristics of the investigated Technosol, which had not yet reached its pedogenetic climax (Séré et al., 2010). In addition, disturbed anthropogenic environments offer a reduced number of available niches, creating communities with little niche differentiation (Korotkevich et al., 2018). 


\section{Functional composition of the Technosol Collembola community}

Our findings showed that the functional indices and life forms of the Collembola community changed over time. Likely influenced by the increase in species richness, functional richness and dispersion increased most in the fourth year. The high functional volume and dispersion occurring in the fourth year indicates that the Technosol community became a more complex system with increasing niche differentiation (Villéger, 2008; Mason et al., 2013). This increase in community functional volume and dispersion suggests an increase of niche complementarity and a better use of resources by organisms (Mason et al., 2005, 2013). These results confirm our first and second hypotheses that the Collembola community would become taxonomically and functionally more diversified over time.

Despite the increase in functional richness and dispersion, the dominance of one ecomorphological group was observed the fourth year. While hemiedaphic Collembola were dominant throughout the study, during the first year, the Collembola community also showed a moderate proportion of epedaphic and euedaphic organisms, which then completely disappeared over time (Table 2). The dominance of hemiedaphic species is probably due to the compost applied to the topsoil, as compost both represents a food resource and is the most suitable habitat for this kind of organism. Euedaphic species represented a very low percentage of total Collembola abundance, probably because of the lack of food resources (Dunger et al., 2002) or the perturbations of the novel substrate (RMQS-Biodiv, 2009; Burrow et al., 2015). The slightly higher proportion of euedaphic species in the first year may have been due to the presence of Mesaphorura, some species of which are pioneers of novel environments (Dunger, 2002; Hopkin, 2007; Santorufo et al., 2015).

The community structure of functional traits during the colonization process was consistent with observations of taxonomic and ecomorphological groups. However, taxonomic diversity per se, and particularly species richness, is less meaningful and informative than functional diversity, which better describes changes in biodiversity as it is based on a more mechanistic point of view (Martins da Silva 
et al., 2016). Passing from the first to the fourth year of the study, a modification of collembolan trait attributes could be observed in the community. The PCA summarizes these observations, showing a higher number of trait attributes during the first year and a reduction in the number of trait attributes over time (Fig. 3). Specifically, during the first year (Fig. 3 left side, Table 4), the community was characterized both by organisms with the trait attributes of pigmentation, furcula, $8+8$ ocelli and spherical body shape (hemiedaphic/epedaphic species), as well as by organisms with no ocelli, small body size and parthenogenetic reproduction: that is, typical traits of species from stable environments (euedaphic species). In the following years (Fig. 3 right side, Table 4), the community became dominated by traits typical of hemiedaphic organisms (Salmon et al., 2014; Santorufo et al., 2015; Joimel et al., 2018). While these hemiedaphic organisms dominated the Technosol community throughout the study, particularly in the fourth year, the proportion became increasingly higher over time. In the fourth year, the increase in functional volume and dispersion together with the increasing proportion of hemiedaphic life forms suggest that hemiedaphic organisms could occupy several different ecological niches. In fact, this hemiedaphic group hosts a number of morphologically diverse species such as Coecobrya tenebricosa, Ceratophysella bengtssoni and Folsomides parvulus.

\section{Conclusion}

Our findings demonstrated that after a relatively short period (four years), a taxonomically and functionally diversified microarthropod community is able to develop in constructed Technosol. Yet although we observed an increase of Collembola species richness and functional richness, showing some potential for increased overall biodiversity, the Technosol appeared to be immature, with a strong dominance of a few common species able to develop in compost. From a taxonomic point of view, the species composition after four years was still very different to French reference values for other land types, with some similarities to arable land. 


\section{Acknowledgements}

This study was carried out by researchers in the TEBIS network (Ecological and Biological Traits of Soil Invertebrates, http://www.reseau-tebis.fr/). Many thanks to the University of Lorraine/ENSAIA Soil and Environment Laboratory (LSE) technical staff for their assistance, particularly Alain Rakoto, as well as the Scientific Interest Group on Brownfields (GISFI). The authors wish to thank their colleagues, in particular Jonathan Bonfanti, Quentin Vincent and Sandrine Salmon, from the BETSI soil invertebrate database project overseen by the Centre for Biodiversity Analysis / Foundation for Biodiversity Research (FRB-CESAB) for their work on functional traits. This project was financed by the GESSOL research programme into the environmental function of soil and the management of soil assets (Biotechnosol project, http://www.gessol.fr/content/biodiversite-et-fonctionnement-d-untechnosol-construit-utilise-dans-la-restauration-de-friche).

\section{Author Contributions}

Conceived and designed the experiments: JC. Performed the experiments: JD, GG. Data analysis, SJ, LS. Data implementation: SJ, LS, AU, MH, JN, CP, JC. Writing-original draft preparation: LS, SJ, JC. Writing - review and editing: AU, MH, CP, JN. Validation: LS, SJ, JC. All authors have read and agreed to the published version of the manuscript.

\section{References}

ADEME, Déchets, Chiffres-clés, Edition 2012, ADEME éditions

Behan-Pelletier, V. M., Winchester, N., 1998. Arboreal oribatid mites diversity: colonizing the canopy. - Applied Soil Ecology 9, 45-51.

BIOTECHNOSOL, 2013. Biodiversité et fonctionnement d'un technosol construit dans la restauration de friches industrielles. Synthèse du rapport final. Programme GESSOL.

Bretfeld, G., 1999. Synopses on paleartic collembolan. In: Dunger, W. (Ed.), Symphy-pleona, vol. 2. Staatliches Museum fur Naturkunde Gôrlitz.

Burrow, C., 2015. Influence des modalités de restauration de sols dégradés sur leur colonisation par une faune du sol fonctionnelle. Mémoire de thèse. Université Lille 1.

Burrow, C., Pernin, C., Lepretre, A., 2018. Influence of connectivity \& topsoil management practices of a constructed technosol on pedofauna colonization: A field study. Appl. Soil Ecol. 123, 416-419. https://doi.org/10.1016/j.apsoil.2017.12.001

Chauvat, M., Ponge, J.-F., 2002. Colonization of heavy metal-polluted soils by collembola: preliminary experiments in compartmented boxes. Appl. Soil Ecol. 21, 91-106. https://doi.org/10.1016/S0929-1393(02)00087-2

Clobert J., Baguette M., Benton T.G., Bullock J.M., 2012. Dispersal ecology and evolution. Oxford: Oxford Univ. Press.

Cortet, J., Griffiths, B.S., Bohanec, M., Demšar, D., Andersen, M.N., Caul, S., E. Birch, A.N., Pernin, C., Tabone, E., de Vaufleury, A., Ke, X., Krogh, P.., 2007. Evaluation of effects of transgenic Bt maize on microarthropods in a European multi-site experiment. Pedobiologia 51, 207218. https://doi.org/10.1016/j.pedobi.2007.04.001

Deeb, M., Desjardins, T., Podwojewski, P., Pando, A., Blouin, M., Lerch, T.Z., 2017. Interactive effects of compost, plants and earthworms on the aggregations of constructed Technosols. Geoderma 305, 305-313. https://doi.org/10.1016/j.geoderma.2017.06.014 
Deeb, M., Grimaldi, M., Lerch, T.Z., Pando, A., Podwojewski, P., Blouin, M., 2016. Influence of Organic Matter Content on Hydro-Structural Properties of Constructed Technosols. Pedosphere 26, 486-498. https://doi.org/10.1016/S1002-0160(15)60059-5

Dray, S., Dufour, A.B., 2007. The ade4 Package: Implementing the Duality Diagram for Ecologists. J. Stat. Softw. 22, 1-20.

Dunger, W., Schulz, H.-J., Zimdars, B., 2002. Colonization behaviour of Collembola under different conditions of dispersal. Pedobiologia 46, 316-327. https://doi.org/10.1078/0031-405600139

Dunger, W., 1999. Synopses on Palaearctic Collembola. 2. Symphypleona. Staatliches Museum für Naturkunde.

Dunger, W., Schlitt, B., 2011. Synopses on Palaearctic Collembola, Volume 6, Part 1: Onychiuroidea: Tullbergiidae (2011): NHBS: Dunger and Bettina Schlitt, Staatliches Museum für Naturkunde. ed.

Dunger, W., Wanner, M. (eds) (1999) Immigration und Sukzession ausgewählter Gruppen der Bodenfauna in terrestrischen Ökosystemen und Bergbaurandflächen. Schlußbericht des BMBF-Forschungsvorhabens BEO/ 51.0339668, Staatliches Museum für Naturkunde Görlitz.

Dunger, W., Schulz, H.-J., Zimdars, B., 2002. Colonization behaviour of Collembola under different conditions of dispersal. Pedobiologia 46, 316-327. https://doi.org/10.1078/0031-405600139

Gisin, H., 1960. Collembolenfauna Europas, Muséum d'Histoire Naturelle. ed. Genève.

Gisin, H., 1943. Ökologie und Lebensgemeinschaften der Collembolen im Schweizerischen Exkursionsgebiet Basels. Rev. Suisse Zool. 50, 131-224.

Grosbellet, C., Vidal-Beaudet, L., Caubel, V., Charpentier, S., 2011. Improvement of soil structure formation by degradation of coarse organic matter. Geoderma 162, 27-38. https://doi.org/10.1016/j.geoderma.2011.01.003

Hafeez, F., Martin-Laurent, F., Béguet, J., Bru, D., Cortet, J., Schwartz, C., Morel, J.-L., Philippot, L., 2012. Taxonomic and functional characterization of microbial communities in Technosols constructed for remediation of a contaminated industrial wasteland. J. Soils Sediments 12, 1396-1406. https://doi.org/10.1007/s11368-012-0563-4

Hågvar, S., 2010. Primary succession of springtails (Collembola) in a Norwegian glacier foreland. Arct. Antarct. Alp. Res. 42422-429

Hedde, M., Nahmani, J., Séré, G., Auclerc, A., Cortet, J., 2018. Early colonization of constructed Technosols by macro-invertebrates. J. Soils Sediments. https://doi.org/10.1007/s11368018-2142-9

Hopkin, S. P. Biology of the springtails: (Insecta: Collembola). OUP Oxford (1997)

Hopkin, S.P., 2007. A Key to the Collembola (springtails) of Britain and Ireland. Field Studies Council, Shrewsbury.

IUSS Working Group WRB. 2015. World Reference Base for Soil Resources 2014, update 2015 International soil classification system for naming soils and creating legends for soil maps. World Soil Resources Reports No. 106. FA0, Rome.

Jangorzo, N.S., Watteau, F., Schwartz, C., 2013. Evolution of the pore structure of constructed Technosols during early pedogenesis quantified by image analysis. Geoderma 207-208, 180-192. https://doi.org/10.1016/j.geoderma.2013.05.016 
Joimel, S., Grard, B., Auclerc, A., Hedde, M., Le Doaré, N., Salmon, S., Chenu, C., 2018. Are Collembola "flying" onto green roofs? Ecol. Eng. 111, 117-124. https://doi.org/10.1016/j.ecoleng.2017.12.002

Joimel, S., Schwartz, C., Hedde, M., Kiyota, S., Krogh, P.H., Nahmani, J., Pérès, G., Vergnes, A., Cortet, J., 2017. Urban and industrial land uses have a higher soil biological quality than expected from physicochemical quality. Sci. Total Environ. 584-585, 614-621. https://doi.org/10.1016/j.scitotenv.2017.01.086

Jordana, R., 2012. Synopses on Palaearctic Collembola, Volume 7, Part 1: Capbryinae \& Entomobryini. Staatliches Museum für Naturkunde.

Korotkevich, A.Yu., Potapov, A.M., Tiunov, A.V., Kuznetsova, N.A., 2018. Collapse of trophic-niche structure in belowground communities under anthropogenic disturbance. Ecosphere 9, e02528. https://doi.org/10.1002/ecs2.2528

Laliberte, E., Legendre, P., 2010. A distance-based framework for measuring functional diversity from multiple traits. Ecology 91, 299-305.

Laliberté, E., Shipley, B., 2011. Measuring functional diversity (FD) from multiple traits, and other tools for functional ecology. R Package Version 10-11.

Lavorel, S., Grigulis, K., McIntyre, S., Williams, N.S.G., Garden, D., Dorrough, J., Berman, S., Quétier, F., Thébault, A., Bonis, A., 2008. Assessing functional diversity in the field - methodology matters! Funct. Ecol. 22, 134-147. https://doi.org/10.1111/j.1365-

2435.2007.01339.xLehmann, A., 2006. Technosols and other proposals on urban soils for the WRB (World Reference Base for Soil Resources). Int. Agrophys. 20, 129-134.

Makkonen, M., Berg, M.P., van Hal, J.R., Callaghan, T.V., Press, M.C., Aerts, R., 2011. Traits explain the responses of a sub-arctic Collembola community to climate manipulation. Soil Biol. Biochem. 43, 377-384. https://doi.org/10.1016/j.soilbio.2010.11.004

Martins da Silva, P., Carvalho, F., Dirilgen, T., Stone, D., Creamer, R., Bolger, T., Sousa, J.P., 2016. Traits of collembolan life-form indicate land use types and soil properties across an European transect. Appl. Soil Ecol. 97, 69-77. https://doi.org/10.1016/j.apsoil.2015.07.018

Marshall, R.E., Farahbakhsh, K., 2013. Systems approaches to integrated solid waste management in developing countries. Waste Manage. 33 (4), 988-1003.

Mason, N.W.H., Mouillot, D., Lee, W.G., Wilson, J.B., 2005. Functional richness, functional evenness and functional divergence: the primary components of functional diversity. Oikos 111, 112-118. https://doi.org/10.1111/j.0030-1299.2005.13886.x

Mason, N. W.H., De Bello, F.,Mouillot, D., Pavoine, S., Dray, S., 2013. A guide for using functional diversity indices to reveal changes in assembly processes along ecological gradients. J. of Veg. Sci. 24, 794-806

Melbourne, B.A., Hastings, A., 2009. Highly Variable Spread Rates in Replicated Biological Invasions: Fundamental Limits to Predictability. Science 325, 1536-1539. https://doi.org/10.1126/science.1176138

Milano, V., Maisto, G., Baldantoni, D., Bellino, A., Bernard, C., Croce, A., Dubs, F., Strumia, S., Cortet, J., 2018. The effect of urban park landscapes on soil Collembola diversity: A Mediterranean case study. Landsc. Urban Plan. 180, 135-147.

https://doi.org/10.1016/j.landurbplan.2018.08.008

Oksanen, J., Blanchet, G., Roeland, K., Legendre, P., Minchin, P.R., O'Hara, R.B., Simpson, G.L., Solymos, P., Stevens, M.H.H., Wagner, H., 2014. Vegan : Community Ecology Package. R Package 280. 
Pey, B., 2010. Contribution de la faune du sol au fonctionnement et à l'évolution des Technosols. Mémoire de thèse. Nancy Université INPL.

Pey, B., Laporte, M.-A., Nahmani, J., Auclerc, A., Capowiez, Y., Caro, G., Cluzeau, D., Cortet, J., Decaëns, T., Dubs, F., Joimel, S., Guernion, M., Briard, C., Grumiaux, F., Laporte, B., Pasquet, A., Pelosi, C., Pernin, C., Ponge, J.-F., Salmon, S., Santorufo, L., Hedde, M., 2014a. A Thesaurus for Soil Invertebrate Trait-Based Approaches. PLoS ONE 9, e108985. https://doi.org/10.1371/journal.pone.0108985

Pey, B., Nahmani, J., Auclerc, A., Capowiez, Y., Cluzeau, D., Cortet, J., Decaëns, T., Deharveng, L., Dubs, F., Joimel, S., Briard, C., Grumiaux, F., Laporte, M.-A., Pasquet, A., Pelosi, C., Pernin, C., Ponge, J.-F., Salmon, S., Santorufo, L., Hedde, M., 2014b. Current use of and future needs for soil invertebrate functional traits in community ecology. Basic Appl. Ecol. 15, 194-206. https://doi.org/10.1016/j.baae.2014.03.007

Ponge, J.-F., Pérès, G., Guernion, M., Ruiz-Camacho, N., Cortet, J., Pernin, C., Villenave, C., Chaussod, R., Martin-Laurent, F., Bispo, A., Cluzeau, D., 2013. The impact of agricultural practices on soil biota: A regional study. Soil Biol. Biochem. 67, 271-284.

https://doi.org/10.1016/j.soilbio.2013.08.026

Potapov, M., 2001. Synopses on Palaearctic Collembola, Volume 3: Isotomidae. Staatliches Museum für Naturkunde.

RMQS-BioDiv Bretagne, 2009. Tome 1. Synthèse générale.

Rokia, S., Séré, G., Schwartz, C., Deeb, M., Fournier, F., Nehls, T., Damas, O., Vidal-Beaudet, L., 2014. Modelling agronomic properties of Technosols constructed with urban wastes. Waste Manag. 34, 2155-2162. https://doi.org/10.1016/j.wasman.2013.12.016

Salmon, S., Ponge, J.F., 2012. Species traits and habitats in springtail communities: A regional scale study. Pedobiologia 55, 295-301. https://doi.org/10.1016/j.pedobi.2012.05.003

Salmon, S., Ponge, J.F., Gachet, S., Deharveng, L., Lefebvre, N., Delabrosse, F., 2014. Linking species, traits and habitat characteristics of Collembola at European scale. Soil Biol. Biochem. 75, 73-85. https://doi.org/10.1016/j.soilbio.2014.04.002

Santorufo, L., Cortet, J., Nahmani, J., Pernin, C., Salmon, S., Pernot, A., Morel, J.L., Maisto, G., 2015. Responses of functional and taxonomic collembolan community structure to site management in Mediterranean urban and surrounding areas. Eur. J. Soil Biol. 70, 46-57. https://doi.org/10.1016/j.ejsobi.2015.07.003

Séré, G., Schwartz, C., Ouvrard, S., Sauvage, C., Renat, J.-C., Morel, J.L., 2008. Soil construction: A step for ecological reclamation of derelict lands. J. Soils Sediments 8, 130-136. https://doi.org/10.1065/jss2008.03.277

Séré, G., Schwartz, C., Ouvrard, S., Renat, J.-C., Watteau, F., Villemin, G., Morel, J.L., 2010. Early pedogenic evolution of constructed Technosols. J. Soils Sediments 10, 1246-1254. https://doi.org/10.1007/s11368-010-0206-6

Skubała, P., 2004. Colonization and development of oribatid mite communities (Acari, Oribatida) on post-industrial dumps. - Wydawnictwo Universytetu Slaskiego, Katowice.

Soil Atlas of Europe, European Soil Bureau Network European Commission, 2005, 128 pp. Office for Official Publications of the European Communities, L-2995 Luxembourg

Status of the world's soil resources: main report., 2015. FAO : ITPS, Rome.

Thibaud, J.-M., Schulz, H.-J., Gama Assalino, M.M. da, 2004. Synopses on Palaearctic Collembola, Volume 4: Hypogastruridae. Staatliches Museum für Naturkunde, Görlitz, Germany. 
Vanhée, B., Devigne, C., 2018. Differences in collembola species assemblages (Arthropoda) between spoil tips and surrounding environments are dependent on vegetation development. Sci. Rep. 8. https://doi.org/10.1038/s41598-018-36315-1

Vidal-Beaudet, L., 2018. Du déchet au Technosol fertile : l'approche circulaire du programme français de recherche SITERRE. VertigO. https://doi.org/10.4000/vertigo.21887

Villéger, S., 2008. Dynamique de la diversité fonctionnelle des communautés de poissons (lagune de Terminos, Mexique) 332.

Villenave, C., Séré, G., Schwartz, C., Watteau, F., Jimenez, A., Cortet, J., 2018. Rapid Changes in Soil Nematodes in the First Years after Technosol Construction for the Remediation of an Industrial Wasteland. Eurasian Soil Sci. 51, 1266-1273. https://doi.org/10.1134/S1064229318100149

Winter, S., Zaplata, M. K., Rzanny, M., Schaaf, W., Fischer, A., Ulrich, W., 2019. Increasing ecological multifunctionality during early plant succession. Plant. Ecol. 220, 499-509.

Yilmaz, D., Bouarafa, S., Peyneau, P., Angulo-Jaramillo, R., Lassabatere, L., 2019. Assessment of hydraulic properties of technosols using Beerkan and multiple tension disc infiltration methods. Eur. J. Soil Sci. ejss.12791. https://doi.org/10.1111/ejss.12791

Zimdars, B., 1994. Synopses on Palaearctic Collembola. 1. Introduction, Tullbergiinae Bagnall, 1935. Staatliches Museum für Naturkunde. 


\section{Figure Captions}

Figure 1. Total Collembola mean density (a) and species number (b) per sample on Technosol along four years after soil construction ( $\mathrm{n}=96$ by years) and comparison with values under arable soil, forest and grassland extracted from Joimel et al. (2017) database. Lower case letters indicate significant differences among Technosol in different years and reference soils.

Figure 2. Graphic displaying the first two axes of the non-metric multidimensional scaling (NMDS) on Collembola species composition in Technosol compared to others land uses. Spiders represents the four years after soil construction ( $n=96$ by years) and communities for forest $(n=304)$, grassland $(n=46)$ and arable land (n=304) uses in French topsoils according to Joimel et al. (2017).

Figure 3. Graphical display of the first two axes of the Principal Component Analysis on the functional composition of Collembola community in Technosol. Labels correspond to community weighted mean (CWM) of 8 functional traits (reproduction type, REP; number of ocelli, Oce; pigmentation, PIG; body length, BL; furcula development, Fur; body shape, BSH, Post-antennal organ, PAO; Scales, SCA). (a) Representation of variables and (b) observations on the first two axes depending on years after soil construction. (Axis $1=43 \%$, Axis $2=21 \%$ ). 
${ }^{*}$ Conflict of Interest Statement

DECLARATION OF INTERESTS

The authors declare they have no known competing financial interests or personal relationships that could have appeared to influence the work reported in this paper 


\section{Highlights}

The Technosol showed successful colonization by microarthropods

Collembola communities increased in taxonomic and functional richness over the years After four years, hemiedaphic Collembola dominated the community

Collembola community in the Technosol remained very different to natural grassland 
Table 1. Description and attributes of the eight morphological, behavioural and physiological traits considered for the trait-based approach of the collembolan community

\begin{tabular}{|c|c|c|}
\hline Trait & Attribute & Abbreviation \\
\hline \multirow[t]{2}{*}{ Body shape } & Spherical & BSH_Sph \\
\hline & Cylindrical & BSH_Cyl \\
\hline \multirow[t]{10}{*}{ Body length } & $<0.5 \mathrm{~mm}$ & BL_0.0.5 \\
\hline & $0.5-1 \mathrm{~mm}$ & BL_0.5.1 \\
\hline & $1-1.5 \mathrm{~mm}$ & BL_1.1.5 \\
\hline & $1.5-2 \mathrm{~mm}$ & BL_1.5.2 \\
\hline & $2-2.5 \mathrm{~mm}$ & BL_2.2.5 \\
\hline & $2.5-3 \mathrm{~mm}$ & BL_2.5.3 \\
\hline & $3-3.5 \mathrm{~mm}$ & BL_3.3.5 \\
\hline & $3.5-4 \mathrm{~mm}$ & BL_3.5.4 \\
\hline & $4-5 \mathrm{~mm}$ & BL.4.5 \\
\hline & $5-7 \mathrm{~mm}$ & BL.5.7 \\
\hline \multirow[t]{2}{*}{ Furcula development } & Absent or vestigial furcula & Fur_0 \\
\hline & Short or long furcula & Fur_1 \\
\hline \multirow[t]{2}{*}{ Pigmentation } & Presence & PIG_1 \\
\hline & Absence & PIG_0 \\
\hline \multirow[t]{3}{*}{ Number of Ocelli } & Without ocelli & Oce_abs \\
\hline & $1+1$ to $7+7$ ocelli & Oce.1_7 \\
\hline & $8+8$ ocelli & Oce. 8 \\
\hline \multirow[t]{2}{*}{ Post-antennal organ } & With post-antennal organ & PAO_1 \\
\hline & Without post-antennal organ & PAO_0 \\
\hline \multirow[t]{2}{*}{ Scales } & With scales & SCA_1 \\
\hline & Without scales & SCA_0 \\
\hline \multirow[t]{2}{*}{ Reproduction type } & Sexual & REP_Sex \\
\hline & Parthenogenesis & REP_Parth \\
\hline
\end{tabular}


Table 2. Percentage distribution ( \pm s.d.) of microarthropods (\%) and Collembola ecomorphological groups (\%) in Technosol along four years after soil construction. Lower case letters indicate significant differences between years; $n=96$ by years; Lines in grey indicate the mean values for forest, grassland and arable land uses in French topsoils according to Joimel et al. (2017)

\begin{tabular}{|c|c|c|c|c|c|c|}
\hline & \multicolumn{3}{|c|}{ Microarthropods composition } & \multicolumn{3}{|c|}{ Ecomorphological groups } \\
\hline & Collembola & Acari & Others & Epedaphic & Hemidaphic & Eudaphic \\
\hline 1 st & $\begin{array}{c}61.5^{\mathrm{b}} \\
( \pm 35.9)\end{array}$ & $\begin{array}{c}27.7^{\mathrm{a}} \\
( \pm 31.6)\end{array}$ & $\begin{array}{c}10.8^{\mathrm{a}} \\
( \pm 17.2)\end{array}$ & $\begin{array}{c}6.8^{\mathrm{a}} \\
( \pm 16.4)\end{array}$ & $\begin{array}{c}77.9^{b} \\
( \pm 28.5)\end{array}$ & $\begin{array}{c}15.3^{\mathrm{a}} \\
( \pm 25.1)\end{array}$ \\
\hline 2nd & $\begin{array}{c}78.9^{\mathrm{b}} \\
( \pm 15.2)\end{array}$ & $\begin{array}{c}17.9^{\mathrm{b}} \\
( \pm 14.1)\end{array}$ & $\begin{array}{c}3.2^{\mathrm{b}} \\
( \pm 4.6)\end{array}$ & $\begin{array}{c}1.4^{\mathrm{b}} \\
( \pm 2.3)\end{array}$ & $\begin{array}{l}98.4^{\mathrm{a}} \\
( \pm 2.5)\end{array}$ & $\begin{array}{c}0.2^{\mathrm{b}} \\
( \pm 1.1)\end{array}$ \\
\hline 3rd & $\begin{array}{c}85.5^{\mathrm{a}} \\
( \pm 12.7)\end{array}$ & $\begin{array}{c}12.5^{\mathrm{c}} \\
( \pm 12.3)\end{array}$ & $\begin{array}{c}2.0^{b} \\
( \pm 2.6)\end{array}$ & $\begin{array}{c}0.1^{\mathrm{b}} \\
( \pm 0.4)\end{array}$ & $\begin{array}{l}98.2^{\mathrm{a}} \\
( \pm 6.1)\end{array}$ & $\begin{array}{c}1.7^{\mathrm{b}} \\
( \pm 6.0)\end{array}$ \\
\hline 4th & $\begin{array}{c}85.8^{\mathrm{a}} \\
( \pm 13.7)\end{array}$ & $\begin{array}{c}11.0^{\mathrm{c}} \\
( \pm 12.5)\end{array}$ & $\begin{array}{c}3.2^{\mathrm{b}} \\
( \pm 4.4)\end{array}$ & $\begin{array}{c}0.5^{\mathrm{b}} \\
( \pm 1.1)\end{array}$ & $\begin{array}{l}98.7^{\mathrm{a}} \\
( \pm 4.0)\end{array}$ & $\begin{array}{c}0.8^{\mathrm{b}} \\
( \pm 4.0)\end{array}$ \\
\hline Forest & 47.6 & 43.3 & 9.0 & 5.2 & 35.0 & 59.8 \\
\hline Grassland & 52.5 & 41.0 & 6.5 & 32.8 & 45.6 & 21.6 \\
\hline Arable land & 25.1 & 68.3 & 6.6 & 35.6 & 50.0 & 14.3 \\
\hline
\end{tabular}


Table 3. Mean values ( \pm s.d.) of taxonomic and functional indices calculated on Collembola communities in Technosol along four years after soil construction. Lower case letters indicate significant differences between years; $n=96$ by years.

\begin{tabular}{ccc|cc}
\hline \multicolumn{2}{c}{ Taxonomical } & \multicolumn{2}{c}{ Functional } \\
\cline { 2 - 5 } & Shannon & Evenness & $\begin{array}{c}\text { Richness } \\
\left(\mathbf{1 0}^{-2}\right)\end{array}$ & Dispersion \\
& & & $5.5^{\mathrm{b}}$ & $0.67^{\mathrm{b}}$ \\
1st & $0.7^{\mathrm{a}}$ & $0.7^{\mathrm{a}}$ & $( \pm 5.9)$ & $( \pm 0.1)$ \\
& $( \pm 0.5)$ & $( \pm 0.4)$ & & \\
& & & & \\
2nd & $0.6^{\mathrm{a}}$ & $0.5^{\mathrm{b}}$ & $3.1^{\mathrm{c}}$ & $0.70^{\mathrm{b}}$ \\
& $( \pm 0.3)$ & $( \pm 0.3)$ & $( \pm 4.0)$ & $( \pm 0.2)$ \\
3rd & $0.4^{\mathrm{b}}$ & $0.5^{\mathrm{b}}$ & $4.9^{\mathrm{b}}$ & $0.71^{\mathrm{b}}$ \\
& $( \pm 0.3)$ & $( \pm 0.3)$ & $( \pm 4.4)$ & $( \pm 0.1)$ \\
4th & $0.7^{\mathrm{a}}$ & $0.5^{\mathrm{b}}$ & $9.2^{\mathrm{a}}$ & $0.81^{\mathrm{a}}$ \\
& $( \pm 0.3)$ & $( \pm 0.2)$ & $( \pm 0.5)$ & $( \pm 0.2)$
\end{tabular}


Table 4. Mean values ( \pm s.d.) of Community weighted mean (\%) of Reproduction type, Furcula development, Pigmentation, Number of ocelli, Body shape, Scales and PAO calculated on Collembola communities in Technosol along four years after soil construction. For binary traits, only one attribute is mentioned. Lower case letters indicate significant differences between years. $\mathrm{PAO}=$ post-antennal organ; $\mathrm{n}=96$ by years.

\begin{tabular}{|c|c|c|c|c|c|c|c|c|}
\hline $\begin{array}{c}\text { Reproduction } \\
\text { type }\end{array}$ & $\begin{array}{c}\text { Furcula } \\
\text { development }\end{array}$ & Pigmentation & \multicolumn{3}{|c|}{ Number of Ocelli } & Body shape & Scales & PAO \\
\hline Sexual & Presence & Presence & $\mathbf{0}$ & $1-7$ & 8 & Cylindrical & Absence & Presence \\
\hline $\begin{array}{c}77^{\mathrm{c}} \\
( \pm 21)\end{array}$ & $\begin{array}{c}87^{\mathrm{b}} \\
( \pm 23)\end{array}$ & $\begin{array}{c}83^{b} \\
( \pm 25)\end{array}$ & $\begin{array}{c}17^{\mathrm{a}} \\
( \pm 25)\end{array}$ & $\begin{array}{c}28^{\mathrm{a}} \\
( \pm 27)\end{array}$ & $\begin{array}{c}55^{\mathrm{c}} \\
( \pm 34)\end{array}$ & $\begin{array}{c}96^{\mathrm{a}} \\
( \pm 7.5)\end{array}$ & $\begin{array}{l}96^{\mathrm{b}} \\
( \pm)\end{array}$ & $\begin{array}{l}90^{\mathrm{bc}} \\
( \pm 14)\end{array}$ \\
\hline $\begin{array}{c}99^{\mathrm{a}} \\
( \pm 1.6)\end{array}$ & $\begin{array}{c}99^{\mathrm{a}} \\
( \pm 1.1)\end{array}$ & $\begin{array}{c}98^{\mathrm{a}} \\
( \pm 3.3)\end{array}$ & $\begin{array}{c}1^{\mathrm{b}} \\
( \pm 1.1)\end{array}$ & $\begin{array}{c}0^{\mathrm{b}} \\
( \pm 2.0)\end{array}$ & $\begin{array}{c}99^{\mathrm{a}} \\
( \pm 2.3)\end{array}$ & $\begin{array}{c}88^{\mathrm{b}} \\
( \pm 6.4)\end{array}$ & $\begin{array}{l}96^{\mathrm{b}} \\
( \pm)\end{array}$ & $\begin{array}{c}96^{\mathrm{ab}} \\
( \pm 6.0)\end{array}$ \\
\hline $\begin{array}{c}91^{\mathrm{b}} \\
( \pm 11)\end{array}$ & $\begin{array}{c}98^{\mathrm{a}} \\
( \pm 6.0)\end{array}$ & $\begin{array}{c}98^{\mathrm{a}} \\
( \pm 6.3)\end{array}$ & $\begin{array}{c}2^{\mathrm{b}} \\
( \pm 6.3)\end{array}$ & $\begin{array}{c}13^{\mathrm{b}} \\
( \pm 18)\end{array}$ & $\begin{array}{c}85^{\mathrm{b}} \\
( \pm 19)\end{array}$ & $\begin{array}{c}84^{\mathrm{c}} \\
( \pm 3.8)\end{array}$ & $\begin{array}{l}99^{\mathrm{a}} \\
( \pm)\end{array}$ & $\begin{array}{c}98^{\mathrm{a}} \\
( \pm 2.9)\end{array}$ \\
\hline $\begin{array}{c}73^{c} \\
( \pm 21)\end{array}$ & $\begin{array}{c}99^{\mathrm{a}} \\
( \pm 3.9)\end{array}$ & $\begin{array}{c}97^{\mathrm{a}} \\
( \pm 5.1)\end{array}$ & $\begin{array}{c}1^{\mathrm{b}} \\
( \pm 4.0)\end{array}$ & $\begin{array}{c}43^{\mathrm{a}} \\
( \pm 36)\end{array}$ & $\begin{array}{c}56^{\mathrm{c}} \\
( \pm 36)\end{array}$ & $\begin{array}{c}91^{\mathrm{b}} \\
( \pm 6.6)\end{array}$ & $\begin{array}{l}92^{\mathrm{b}} \\
( \pm)\end{array}$ & $\begin{array}{c}92^{\mathrm{c}} \\
( \pm 11)\end{array}$ \\
\hline
\end{tabular}



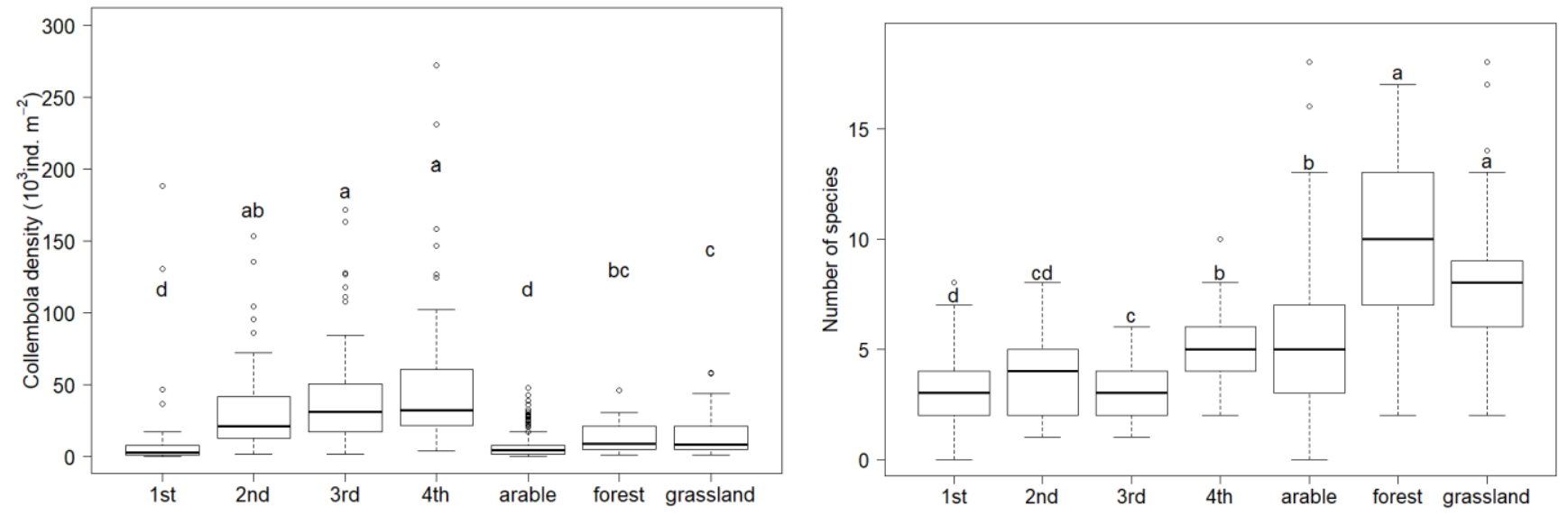

Fig. 1 


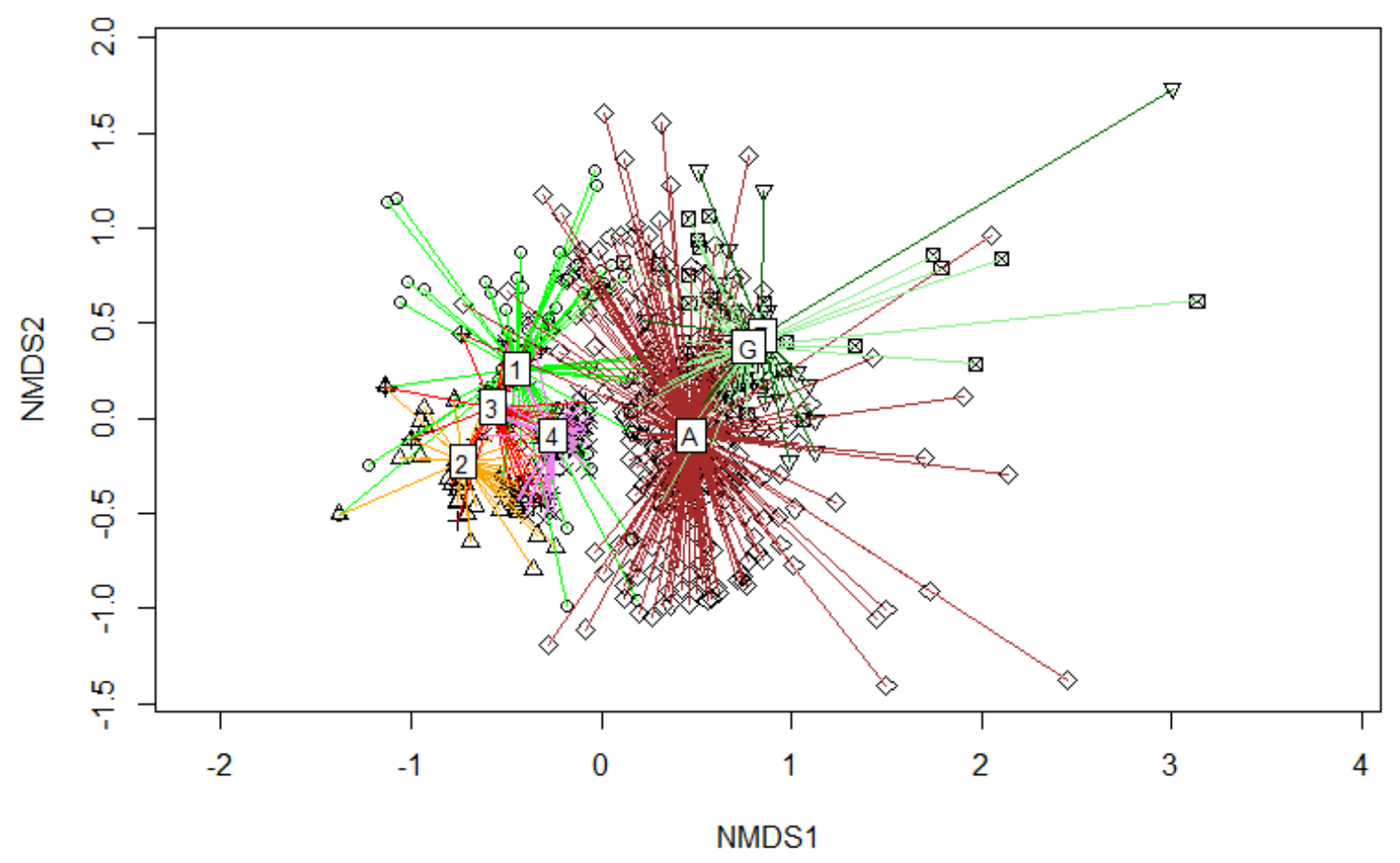

Fig. 2 


\section{Figure}

Click here to download Figure: Fig.3.pdf

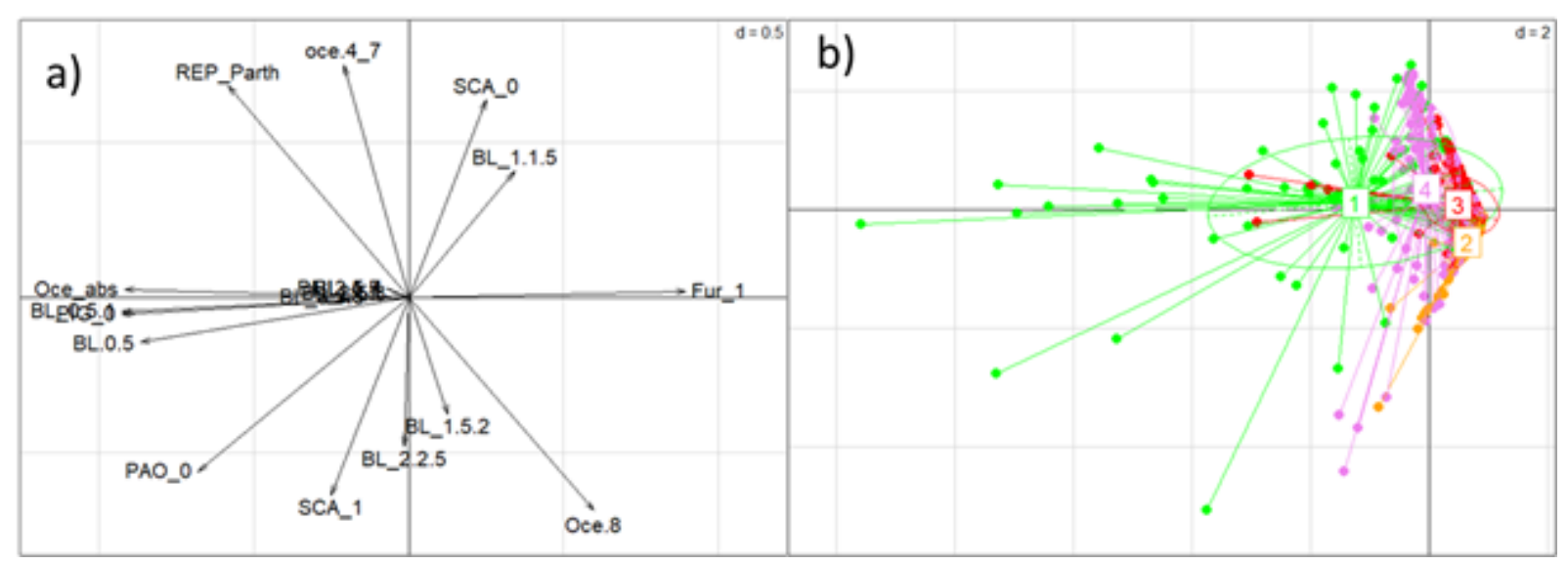

Fig. 3 
Supplementary Material
Click here to download Supplementary Material: Suppelementary material_STable 1.docx Click here to download Supplementary Material: Suppelementary materialstable 1 docx theng

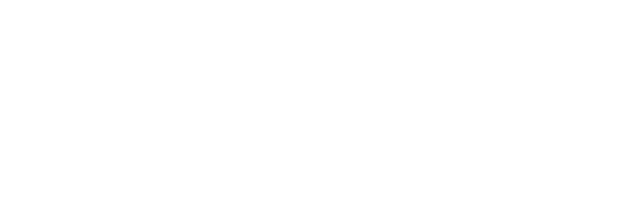
(1) (1) (1) (1) (1) (1) . . . . . . . . 